\title{
One-Dimensional Coordination Polymers of Dihydrobis(1,2,4-triazol-1-yl)borate Ruthenium(II) Complex
}

\author{
Kyoung-Tae Youm, Seong Huh, ${ }^{*}$ Youngmee Kim, ${ }^{* * *}$ Seongsoon Park, and Moo-Jin Jun \\ Department of Chemistry, Yonsei University, Seonl 120-749, Korea. "E-mail: shuh69@gmail.com; mijun@yonseiackr \\ 'Division of Nano Sciences, Ewha Womans University, Seoul 120-750, Korea. "E-mail: ymeekim@ewha.ackr. \\ ${ }^{3}$ Department of Chemistry, Center for Nano Bio Applied Technology, and Institute of Basic Sciences, \\ Sungshin Women's University, Seoul 136-742, Korea \\ Received July 15,2006
}

Key Words : Coordination polymer, Ruthenium complex, Copper complex, Bimetallic complex

Increasing interest in coordination and organometallic polymers lies in the various intriguing properties of welldesigned inorganic polymer materials. 'A variety of attempts have been made to synthesize multidentate ligands which can bridge various metal centers. Ambidentate poly(triazolyl)borate ligands $\left[\mathrm{H}_{n} \mathrm{~B}(\mathrm{tz})_{4-\mathrm{n}}\right]^{-}(\mathrm{n}=1$ and $2, \mathrm{tz}=1,2,4-$ triazol-1-yl) $)^{2.3}$ are good candidates for multidimensional network topologies. ${ }^{+.5}$ It was revealed that both the exodentate (4-position) and endodentate (2-position) nitrogen atoms of the triazolyl rings have comparable electron density to coordinate competitively to metal centers from the theoretical calculation and the ${ }^{15} \mathrm{~N}$ NMR study. ${ }^{6}$ It was frequently observed that the poly(triazoly) borate ligands induce metal ions to form multidimensional coordination polymers through the coordinations of exodentate $\mathrm{N}$ atoms whose electron density is higher than the endodentate $\mathrm{N}$ atoms. However, in the case of $\left[\mathrm{HB}(\mathrm{tz})_{3}\right]^{-}$, tridentate chelated monomers $\mathrm{M}\left[\eta^{3}-\mathrm{HB}(\mathrm{tz})_{3}\right]_{2}\left(\mathrm{M}=\mathrm{Fe}^{2 !}, \mathrm{Co}^{21}, \mathrm{Cu}^{21}\right.$ and $\left.\mathrm{Zn}^{21}\right)^{3}$ are exclusively isolated, and these results are explained by a combination of chelate and kinetic effect. ${ }^{\Sigma}$ Discrete $\mathrm{Ag}^{\mathrm{l}}$ and $\mathrm{Cu}^{\mathrm{I}}$ complexes bearing a bidentate dihydrobis $(1,2,4-$ triazolyl)borate through endodentate coordination such as $\mathrm{Cu}(\mathrm{L})_{n}\left[\eta^{2}-\mathrm{H}_{2} \mathrm{~B}(\mathrm{tz})_{2}\right](\mathrm{L}=$ aryl phosphines, $\mathrm{n}=1$ or 2$)$, $\operatorname{Ag}(\mathrm{L})_{2}\left[\eta^{2}-\mathrm{H}_{2} \mathrm{~B}(\mathrm{tz})_{2}\right]\left(\mathrm{L}=\right.$ aryl phosphines), $\mathrm{Ag}(\mathrm{dppf})\left[\eta^{2}-\right.$ $\left.\mathrm{H}_{2} \mathrm{~B}(\mathrm{tz})_{2}\right] \quad(\mathrm{dppf}=1,10$-bis(diphenylphosphino)fenocene $)$ and their polymeric derivatives were recently reported. ${ }^{7}$ In these cases, however, the dihydrobis $(1,2,4$-triazolyl)borate ligands coordinate to the same type of ions to constitute 1D homometallic polymer networks.

In order to develop efficient heterometallic polymeric systems whose physicochemical properties can be systematically tuned, we are pursuing to prepare discrete mononuclear complexes bearing anionic dihydrobis $(1,2,4$-triazolyl)borate ligands through endodentate coordinations instead of exodentate coordinations. Discrete complexes having a ligand (or ligands) through a bidentate coordination of the two endodentate $\mathrm{N}$ atoms could potentially serve as metalloligands for the engineering of $1 \mathrm{D}$ modular structure through additional coordinations of the exodentate $\mathrm{N}$ atoms to two other transition metal moieties. Recently we were able to prepare discrete mononuclear $\mathrm{Fe}\left[\mathrm{HB}(\mathrm{tz})_{3}\right]_{2} \cdot \mathrm{ClO}_{4}$ and $\mathrm{Ag}(\mathrm{L})$ $\left(\mathrm{PPh}_{3}\right)(\mathrm{L}=$ hydrotris(3,5-dimethyl-4-(4-pyridyl)pyrazolyl)- borate) to use them as building blocks for novel 3D or 2D functional networks. ${ }^{8}$ On the other hand, the reaction between $\mathrm{Mn}(\mathrm{TPP}) \cdot \mathrm{ClO}_{4}$ and $\mathrm{K}\left[\mathrm{H}_{2} \mathrm{~B}(\mathrm{tz})_{2}\right]$ only afforded a discrete mononuclear $\mathrm{Mn}(\mathrm{TPP})\left(\mathrm{H}_{2} \mathrm{O}\right)\left[\eta^{\prime}-\mathrm{H}_{2} \mathrm{~B}(\mathrm{tz})_{2}\right]$ instead of $1 \mathrm{D}$ polymeric structures because of a steric bulk of TPP ligand (TPP is 5,10,15,20-tetraphenylporphine). ${ }^{9}$

Here we report a new metalloligand having a dihydrobis$\left(1,2,4\right.$-triazolyl)borate, $\mathrm{RuH}(\mathrm{CO})\left(\mathrm{PPh}_{3}\right)_{2}\left[\eta^{2}-\mathrm{H}_{2} \mathrm{~B}(\mathrm{tz})_{2}\right]$ (1) and its successful applications to $1 \mathrm{D}$ supramolecular systems through self-assembly. Because 1 might have catalytic activities for the hydrogenation of ketones and aldehydes under hydrogen atmosphere, the 1D polymers of 1 could be used as recyclable heterogeneous catalysts. The compound 1 was obtained in good yield from the reaction of RuHCl(CO) $\left(\mathrm{PPh}_{3}\right)_{3}{ }_{3}^{10}$ with $\mathrm{K}\left[\mathrm{H}_{2} \mathrm{~B}(\mathrm{tz})_{2}\right]^{2}$ (Figure 1). The compound 1 was fully characterized by ' $\mathrm{H}$ and $\left.{ }^{3} \mathrm{P} P{ }^{\prime}{ }^{\prime} \mathrm{H}\right\} \mathrm{NMR}$, IR, and elemental analysis. A triplet resonance signal of the hydride ligand from ${ }^{1} \mathrm{H} N M R$ and a singlet peak of two $P$ atoms from ${ }^{3} \mathrm{P}\left\{{ }^{\prime} \mathrm{H}\right\}$ NMR clearly indicate that the proposed structure of 1 which is an ideal geometry as a metalloligand. The entire coordination environment is same to the crystallographically characterized $\mathrm{RuH}(\mathrm{CO})\left[\mathrm{P}(p-\mathrm{Tolyl})_{3}\right]_{2}\left[\eta^{2}-\mathrm{H}_{2} \mathrm{~B}(\mathrm{tz})_{2}\right]$ and $\mathrm{RuH}(\mathrm{CO})\left(\mathrm{AsPh}_{3}\right)_{2}\left[\eta^{2}-\mathrm{H}_{2} \mathrm{~B}(\mathrm{pz})_{2}\right]$ (pz is pyrazol-1-yl). ${ }^{11}$

Unlike other insoluble dihydrobis(triazolyl)borate derivatives, the monomer 1 shows a good solubility in halogenated hydrocarbon solvents. The reactions of 1 with 1 or 2 equivalent $\mathrm{Cu}(\mathrm{OAc})_{2} \cdot \mathrm{H}_{2} \mathrm{O}$ afford well-defined $1 \mathrm{D}$ heterometallic polymers $\left\{\left[\mathrm{Cu}_{2}(\mathrm{OAc})_{4}\right][1]\left[\mathrm{Cu}\left(\eta^{1}-\mathrm{OAc}\right)_{2}\right][1]\right\}_{n}$ (2) and $\left\{[1]\left[\mathrm{Cu}_{2}(\mathrm{OAc})_{4}\right] \cdot\left(\mathrm{CH}_{2} \mathrm{Cl}_{2}\right)_{2}\right\}_{n}(3)$, respectively, which contain lantem-type dicopper moieties, $\mathrm{Cu}_{2}(\mathrm{OAc})_{4}{ }^{12}$ Single crystal x-ray crystallographic studies of $\mathbf{2}$ and $\mathbf{3}$ confirm the

$$
\text { RuHCl}(\mathrm{CO})\left(\mathrm{PPh}_{3}\right)_{3}+\mathrm{K}\left[\mathrm{H}_{2} \mathrm{Btz} z_{2}\right]
$$

Figure 1. Reaction scheme of RuHCl(CO) $\left(\mathrm{PPh}_{3}\right)$; and $\mathrm{K}^{\prime}\left[\mathrm{H}_{2} \mathrm{~B}(\mathrm{tz})\right]$. 
(a)

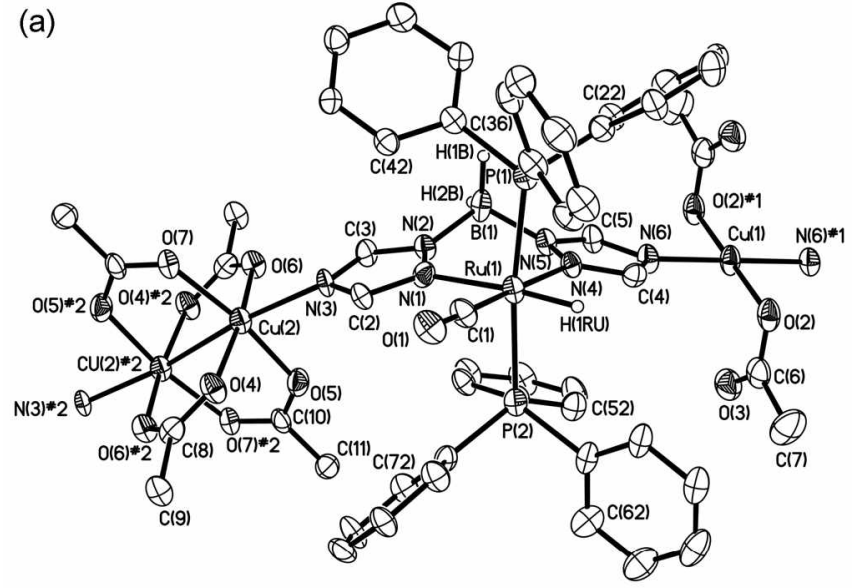

(b)

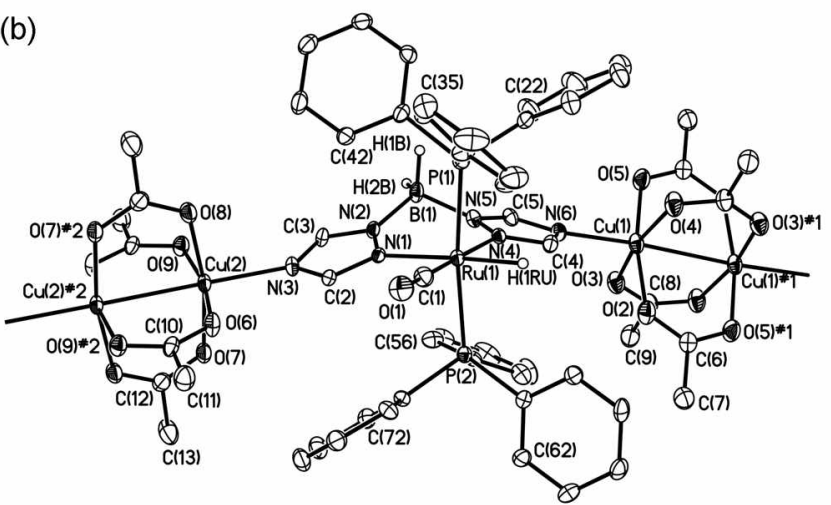

Figure 2. (a) Repeating unit of ID coordination polyıner 2. Selected bond distances $(\AA)$ and angles $\left({ }^{\circ}\right)$ : $\mathrm{Cu}(1)-\mathrm{N}(6) 1.983(8)$, $\mathrm{Cu}(1)-\mathrm{O}(2) 1.959(8), \mathrm{Cu}(2)-\mathrm{N}(3) 2.174(8), \mathrm{Cu}(2) \cdots \mathrm{Cu}(2) \mathrm{b} 2.639(3)$, Ru(I)-N(1) 2.190(9), Ru(I)-N(4) 2.126(8), N(1)-Ru(I)-N(4) 89.4(3), $\mathrm{P}(1)-\mathrm{Ru}(\mathrm{I})-\mathrm{P}(2)$ 173.09(10). Symunetry codes $\mathrm{a}:-\mathrm{x}+1,-\mathrm{y}-\mathrm{I}, \mathrm{z}, \mathrm{b}$ : $-\mathrm{x}+1,-\mathrm{y}-2,-\mathrm{z}$. (b) Crystal structure of $1 \mathrm{D}$ coordination polymer 3 .

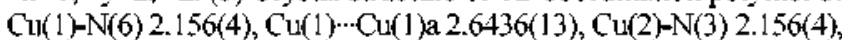
$\mathrm{Cu}(2) \cdots \mathrm{Cu}(2) \mathrm{b} 2.6303(12), \mathrm{Ru}(\mathrm{I})-\mathrm{N}(\mathrm{I}) 2.187(4), \mathrm{Ru}(\mathrm{I}) \mathrm{N}(4) 2.149$ (4), N(1)-Ru(1)-N(4) 87.88(15), P(1)-Ru(1)-P(2) 173.34(5). Symunetry codes $a:-x+1,-y+1, z, b:-x+1,-y,-z$. Hydrogen atoms except for $\mathrm{H}(1 \mathrm{Ru})$ and methylenechloride solvates are omitted for clarity.

proposed structure of 1 and show that 1 indeed behaves as a good building block to connect other metal centers because of the vacant exodentate $\mathrm{N}$ atoms. As shown Figure 2(a), 2 is consisted of altemating $\mathrm{Cu}_{2}(\mathrm{OAc})_{4}$ and $\mathrm{Cu}(\mathrm{OAc})_{2}$ units connected by 1 . Therefore, 2 contains an unique unsymmetrical repeating unit. Two different exodentate $N(6)$ atoms are bound to $\mathrm{Cu}(1)$ atom which is further coordinated by two acetate ligands in $\eta^{\prime}$-mode with $\mathrm{Cu}(1)-\mathrm{O}(2)$ distance of $1.959(8) \AA$. The interaction between $\mathrm{Cu}(\mathrm{I})$ and $\mathrm{O}(3)$ is very weak with the distance of 2.661 (8) $\AA$. The equatorial positions of $\mathrm{Cu}_{2}(\mathrm{OAc})_{4}$ are occupied by other exodentate $\mathrm{N}(3)$ atoms with the length of $2.174(8) \AA$ which is in the range of bonding distances between dicopper complex and typical $\mathrm{N}$ donor atoms $(2.12-2.25 \AA) .^{13}$ Figure $2(\mathrm{~b})$ shows the crystal structure of 3 . Unlike 2 , the repeating unit of 3 has $\mathrm{I}: \mathrm{I}$ ratio of 1 and $\mathrm{Cu}_{2}(\mathrm{OAc})_{4}$. The corresponding $1 \mathrm{D}$ polymer is relatively linear compared with 2 . Exodentate $\mathrm{N}$ atoms $\mathbb{N}(3)$ and $N(6)$ ) of 1 coordinate dicopper units in the length of $2.156(4) \AA$ and which are slightly shorter than those of 2. It is interesting to note that two different ID modular structures were obtained by a simple control of the reactant ratio. Reaction of 1 with $\mathrm{Rh}_{2}\left(\mathrm{O}_{2} \mathrm{CMe}\right)_{4} \cdot 2 \mathrm{MeOH}$ in boiling acetone solution rapidly produced pink-colored ID polymer $\left\{[1]\left[\mathrm{Rh}_{2}\left(\mathrm{O}_{2} \mathrm{CMe}\right)_{4}\right] \xi_{n}\right.$ (4). Reactions between 1 and $\mathrm{Mo}_{2}\left(\mathrm{O}_{2} \mathrm{CCF}_{3}\right)_{4}$ also lead to the formation of yellow ID polymer $\left\{[1]\left[\mathrm{Mo}_{2}\left(\mathrm{O}_{2} \mathrm{CCF}_{3}\right)_{4}\right]\right\}_{\text {n }}(5)$. Both 4 and 5 have a similar structure like $\mathbf{3}$ based on elemental analysis. However, we were unable to grow X-ray quality crystals.

In summary, the discrete mononuclear complex 1 serves as a good building block for heterometallic $1 \mathrm{D}$ coordination polymers with various lantent-type dimers. The different molar ratio of 1 with $\mathrm{Cu}(\mathrm{OAc})_{2} \cdot \mathrm{H}_{3} \mathrm{O}$ afforded structurally unique 2 and 3 , respective]y. Both $\left\{[1]\left[\mathrm{Rh}_{2}\left(\mathrm{O}_{2} \mathrm{CMe}\right)_{4}\right]\right\}_{n}$ and $\left\{[1]\left[\mathrm{Mo}_{2}\left(\mathrm{O}_{2} \mathrm{CCF}_{3}\right)_{4}\right]\right\}_{n}$ were also obtained as stable solids. This unique modular approach enabled us to prepare well defined ID coordination polymers in which two different transition metal moieties were preserved as a form of single strand. In order to expand this strategy, we are investigating other functional complexes containing dihydrobis $(1,2,4-$ triazolyl)borate ligands.

\section{References}

I. (a) Archer, R. D. Inorganic and Organonetallic Polymers; WileyVCH: 200l. (b) Kitagawa, S.; Kitaura, R.; Noro, S.-I. Angew: Chem. Int, Ed. Engl. 2004, 43, 2334. (c) Fujita, M.; Kwon, Y. J.; Washizu, S.; Ogura, K. J. Am. Chem. Soc, 1994, I16, I15l. (d) Huh, S.; Youm, K.-T.; Park, Y, J.; Lough, A. J.; Ohba, M.; Jun, M.-J. Bull. Korean Chent. Soc. 2005, 26, 1031. (e) Suh, M. P.; Ko, J. W. Choi, H. J. J. Am. Chem. Soc. 2002, 124, 10976. (f) Seo, J. S.; Whang, D.; Lee, H.; Jun, S. I.; Oh, J.; Jeon, Y. J.; Kim, K. Nature 2000, 404,982.

2. Janiak, C.; Scharmann, T. G.; Hemling, H.; Lentz, D.; Pickardt, J. Chem. Ber, 1995, 128, 235.

3. Janiak, C. Chem. Ber, 1994, $/ 27,1379$.

4. Janiak, C.; Scharmann, T. G.; Green, J. C.; Parkin, R. P. G.; Kolm, M. J.; Riedel, E.; Mickeler, W.; Elguero, J.; Claramunt, R. M.; Sanz, D. Chem, Em, J. 1996, 2, 992 .

5. Janiak, C.; Hemling, H. J. Chem. Soc, Dahon Thans. 1994, 2947.

6. Janiak, C; Scharmann, T. G.; Albrecht, P; Marlow, F; Macdonald, R.J. An. Chen. Soc. 1996, /18, 6307.

7. (a) Lobbia, G. G.; Pellei, M.; Pettinari, C.; Santini, C.; Skelton. B. W.; Somers, N.; White, A. H. Dalton Trans. 2002, 2333. (b) Lobbia, G G.; Pelleit, M.; Pettinari, C.; Santini, C.; Skelton, B. W.; White, A. H. Inorg. Chin. Acta 2005, 358, 1162.

8. (a) Youm, K.-T.; Kim, M. G.; Ko, J.; Jun, M.-J, Angew, Chem. Int. Ed. Engl. 2006, 45, 4003. (b) Youm, K.-T.; Huh, S.; Park, Y. J.; Park. S.; Choi, M.-G., Jun, M.-J. Chen. Coninitm. 2004, 2384.

9. Huh, S.; Youm, K.-T.; Lough, A. J. Acta Cnłs. 2004, E60, in895.

10. Ahmad, N.; Levinson, J. J.; Robinson, S. D.; Uttely, M. F. Inorg. Synth. 1974, 15, 48.

11. (a) Huh, S.; Park, Y. J.; Lough, A. J.; Jun, M.-J. Acta Cnsst. 2000, C56, 416. (b) Huh, S.; Kim, Y.; Park, S.; Park, T.-J.; Jun, M.-J. Acta Cryst 1999, C55, 850.

12. Supporting Information is available at $h t p-/ / w w w i k c s n e t . o r k r /$ $b k c s$ or from the authors.

13. Neels, A.; Stoeckli-Evans, H.; Escuer, A.; Vicente, R, Inorg. Chem. 1995, 34, 1946. 